\title{
Late Variscan stress-field rotation initiating escape tectonics in the south-western Bohemian Massif: a far field response to late-orogenic extension
}

\author{
Steffen H. BÜTTNER
}

Department of Geology, Rhodes University, Grahamstown, South Africa; s.buettner@ru.ac.za

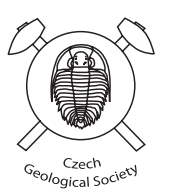

\begin{abstract}
The late Variscan tectonic evolution of the Mühlzone, located at the south-western margin of the Bohemian Massif, is characterized by subhorizontal magmatic shearing under low-differential stress conditions in intrusive and in situ granites of the South Bohemian Batholith. The magmatic shearing converted into ductile shearing and escape tectonics along conjugate strike-slip zones during the late stage of magma solidification ( $\sim 325 \mathrm{Ma})$. Escape tectonics lasted for at least $30 \mathrm{Ma}$. The transition from subhorizontal to strike-slip shearing reflects the rotation of the palaeo-stress field by $\sim 76^{\circ}$ around an axis approximately parallel to $\sigma_{1}$. Via a transient high-temperature stage of solid-state deformation the rotation caused $\sigma_{2}$ and $\sigma_{3}$ almost to swap positions during continuous contraction and cooling of the crust from $>700^{\circ} \mathrm{C}$ to $>500{ }^{\circ} \mathrm{C}$. The primary factor governing stress-field rotation in the Mühlzone were far-field effects of the regional tectonic evolution, specifically stress release by NE-SW crustal extension at the eastern margin of the Bohemian Massif. Extensional strain reduced the magnitude of the subhorizontal ENE-WSW oriented $\sigma_{2}$ to values below the magnitude of the steep $\sigma_{3}$, which most likely remained constant. The $\sigma_{1}$ stress vector maintained a shallow SSE plunging orientation throughout the Late Variscan evolution.

Stress-field rotation and the conversion from subhorizontal to steep shearing are favoured by deformation under low differential stress. High temperatures of metamorphism, or melt present in migmatites or plutons, provide the low shear strength that is required for deformation at low differential stress. Hence, in crust composed of high-grade metamorphic or partially molten rocks, small changes in the tectonic environment can be sufficient for stress-field rotation leading to significant changes in the tectonic style.
\end{abstract}

Keywords: Palaeo-stress determination, magmatic shearing, ductile strike-slip zones, continent collision, South Bohemian Batholith. Received: 18 January 2007; accepted 23 May 2007; handling editor: V. Janoušek

\section{Introduction}

In the southern Bohemian Massif (Fig. 1a) the Late Variscan tectonometamorphic evolution ( $\sim 340-280 \mathrm{Ma})$ has been interpreted, and is widely accepted, as related to a continent-collisional setting. High-temperature and medium- to high-pressure metamorphism in continental and oceanic crust, caused by subduction of the Palaeo-Tethys and parts of the adjacent continental margin underneath Laurasia, was followed by nappe stacking and transport, crustal thickening and subsequent crustal collapse (e.g., Fritz and Neubauer 1993; O'Brien and Carswell 1993; Finger and Steyrer 1995; Büttner and Kruhl 1997; Roberts and Finger 1997). The collapse of the Variscan crust was accompanied by formation and intrusion of the South Bohemian Batholith. Most evidence for this scenario provided the investigation of high-grade metamorphic nappe sequences, such as Drosendorf and Gföhl units, at the south-eastern and eastern margin of the Bohemian Massif and in central Bohemia (e.g., O'Brien and Carswell 1993; Fiala 1995, and references therein). These units represent tectonically high levels in the Variscan nappe pile and are regarded as allochthonous. This view has been challenged recently (e.g., Štípská et al. 2004; Racek et al. 2006) who presented an alternative model for the tectonometamorphic evolution of the eastern margin of the Bohemian Massif.

The Mühlzone (Figs 1a, b), which is the focus of this work, belongs to the lowest crustal levels exposed in the Bohemian Massif and most likely is part of the autochthonous Laurasian crust. The present study investigates the variation of the palaeo-stress field orientation during the late stage of the Variscan orogeny at this relatively low crustal level. Palaeo-stress field variations have been determined using magmatic shear fabrics in granites, coeval solid-state fabrics in the granites' country rocks, and mylonitic fabrics from conjugate ductile shear zones cross-cutting the granites. These shear zones developed after granite solidification. This allows monitoring the response of the crust to contractional regional tectonics during magma emplacement and solidification, and subsequent cooling to amphibolite- and greenschist facies conditions. Some new geochronological data on the timing of the magmatic event within the Mühlzone allow comparison and correlation with the solid-state overprint in the adjacent ductile shear zones. This study correlates 


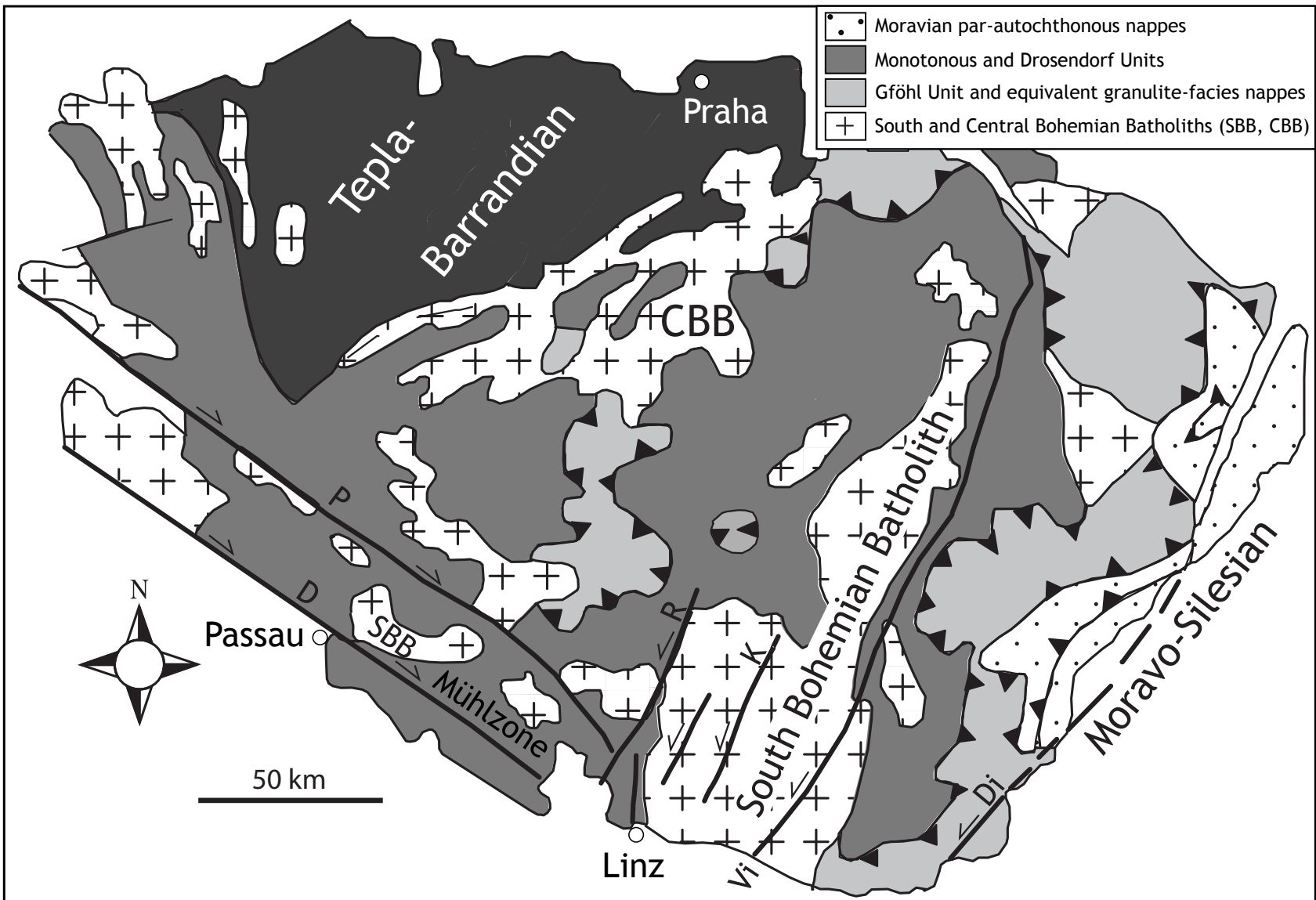

Fig. 1a Simplified geological map of major structural and lithological units in the southern Bohemian Massif (modified after Dallmeyer et al. 1995). Shear zones: D Donau, P Pfahl, R Rodl, K Karlstift, Vi Vitis, Di Diendorf.

stress-field variations at mid-crustal level with the Late Variscan evolution of the southern Bohemian Massif, specifically with regard to contrasting but kinematically and dynamically linked processes at mid- and uppercrustal level.

\section{Geological setting}

The investigation of higher structural levels of the Variscan nappe pile, such as the Drosendorf and Gföhl units, tectonically overlying the schists, gneisses and migmatites of the Monotonous Unit, has provided evidence for the pre-, syn-, and post-collisional stages of the orogeny (e.g., O'Brien and Carswell 1993). Subduction-related high-pressure/high-temperature metamorphism $(\sim 350$ $370 \mathrm{Ma}$; Carswell and O'Brien 1993), collision-related exhumation, nappe transport and crustal thickening have been proposed for this region (e.g., Carswell and O'Brien 1993; Fritz and Neubauer 1993; O'Brien and Carswell 1993). Crustal thickening in the southern Bohemian Massif was accomplished by nappe stacking of the Drosendorf and Gföhl units and their subsequent north- to north-northeast directed thrusting onto the Monotonous
Unit under upper amphibolite to granulite facies conditions ( $D_{1}$ in Fritz and Neubauer 1993 and in Büttner and Kruhl 1997). The Monotonous Unit, which only close to the nappe contact shows some evidence of top-to-thenorth kinematics, is presumed to be autochthonous.

The emplacement of the Variscan nappe pile in Lower Austria has been dated at $\sim 340 \mathrm{Ma}$ (U-Pb zircon and monazite data; e.g., Friedl et al. 1993, 2003). Subsequent isothermal decompression and collapse of the thickened crust was completed by c. 333 Ma (Friedl et al. 1993; $\mathrm{D}_{2}$ in Büttner and Kruhl 1997) leading to the high-temperature/low-pressure regional metamorphism that is seen throughout the southern Bohemian Massif. In response to the uplift and exhumation of the Moldanubian crust the upper parts of the Variscan nappe pile were thrusted eastwards over the Moravian foreland (Fritz and Neubauer 1993; Büttner and Kruhl 1997). Crustal uplift, documented by the isothermal decompression $P-T$ paths in the Moldanubian (e.g., O'Brien and Carswell 1993; Büttner and Kruhl 1997), was probably most intense in the centre and in the west of southern Bohemia and Upper Austria, suggested by the exposure of the deepest crustal levels in these areas (Mühlzone and parts of eastern Bavaria). Crustal uplift also might have caused 


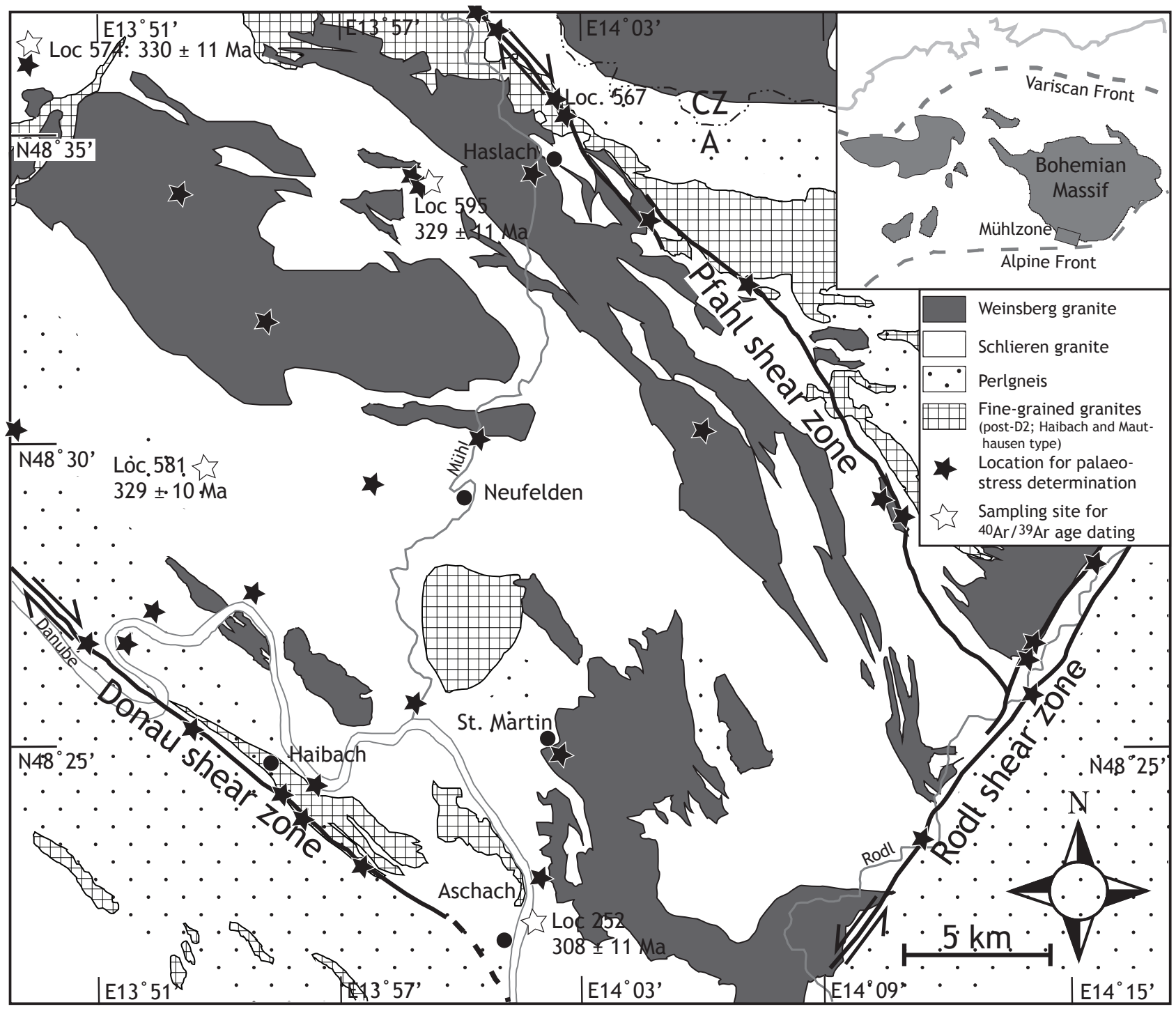

Fig. 1b Simplified geological map of the Mühlzone, Upper Austria (modified after Frasl et al. 1965). Inset: Outcrop of the Variscan belt in central Europe (modified after Franke 1989).

the Late Variscan $(<340 \mathrm{Ma})$ displacement of the higher tectonic units away from this area (Fig. 5 in Urban and Synek 1995; Büttner and Kruhl 1997).

In central Bohemia, collapse-related normal shearing between $340 \mathrm{Ma}$ and $320 \mathrm{Ma}$ along the West and Central Bohemian shear zones led to at least $10 \mathrm{~km}$ uplift of the Moldanubian sensu stricto relatively to the Teplá-Barrandian (Scheuvens and Zulauf 2000; Zulauf et al. 2002). The timing of the collapse in the Teplá-Barrandian is roughly compatible with the uplift and exhumation in southern Bohemia. However, the kinematic relationship of processes in central and southern Bohemia is still poorly constrained.

Recently, an alternative model has been presented for the late phase of tectonic evolution at the eastern margin of the Bohemian Massif (e.g., Štípská et al. 2004; Racek et al. 2006). The authors challenged the established models of nappe tectonics and proposed syn-convergent exhumation by vertical ductile extrusion of high-pressure granulites during $\mathrm{E}-\mathrm{W}$ compression, followed by eastward thrusting of Moldanubian units over a Brunian indenter. However, exhumation and erosion during the uplift of the Moldanubian Zone is well established not only from isothermal decompression $P-T$ paths but also from dramatically increasing late-Viséan deposition rates in flysch and molasse basins in the Moravo-Silesian foreland (Cháb and Suk 1976; Dvořák 1995; Hartley and Otava 2001).

The formation and emplacement of the early and large granitic masses in the South Bohemian Batholith (Weinsberg- and Eisgarn-type granitoids; Gerdes et al. 2003) followed uplift and collapse in southern Bohemia. At the current level of exposure the batholith covers approximately $10000 \mathrm{~km}^{2}$ in northern Austria, the southern 

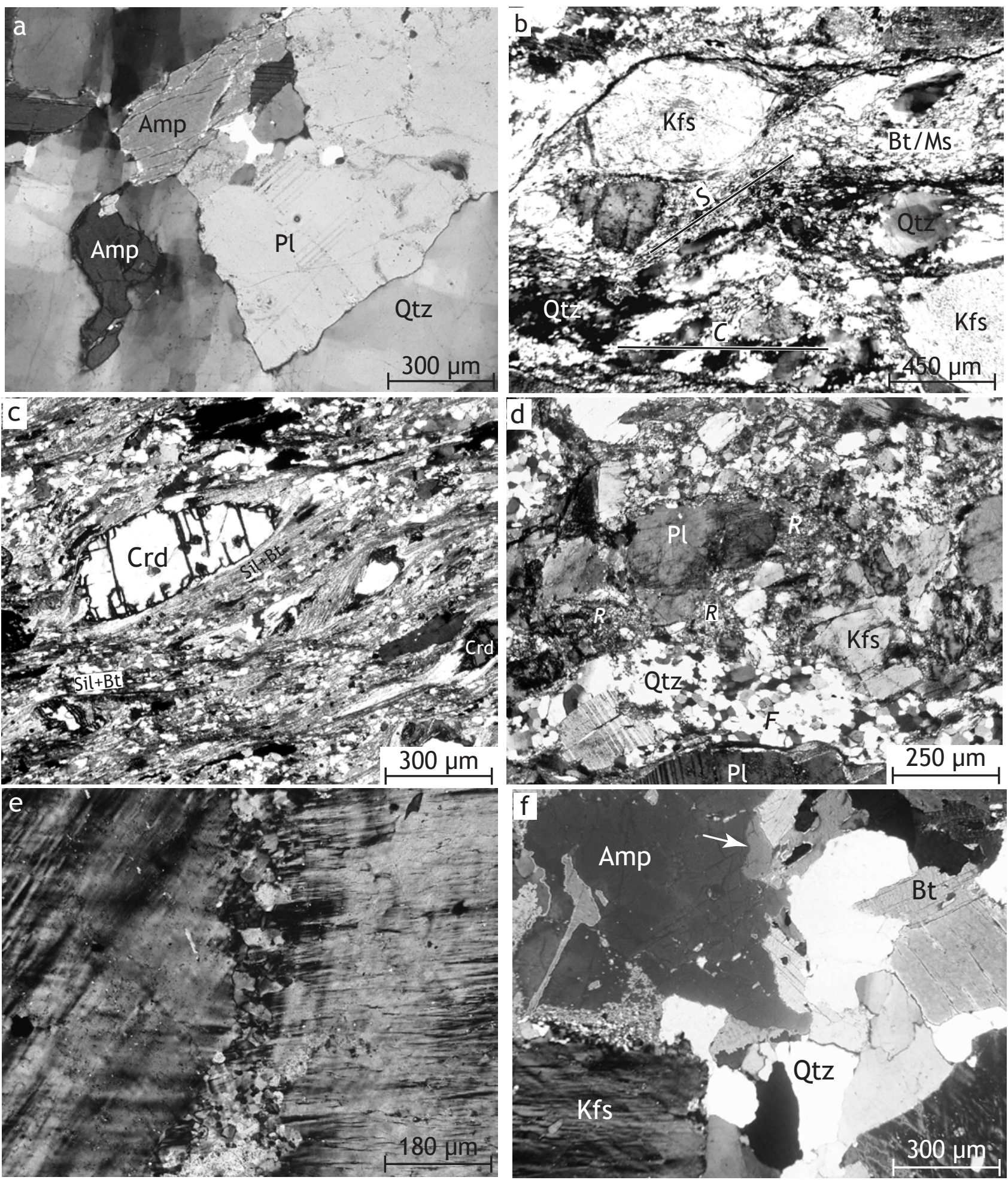

Fig. 2 Photomicrographs of $\mathrm{D}_{2}$ and $\mathrm{D}_{3}$ fabrics of the Mühlzone and adjacent ductile shear zones. All images are taken in cross-polarised light. Mineral abbreviations according to Kretz (1983). a - Magmatic fabrics in Schlieren granite (sample 595). Large quartz crystals fill the interstices between amphibole and plagioclase phenocrysts. Apart from chessboard patterns in quartz the rock is undeformed. $\mathbf{b}-\mathrm{S}-\mathrm{C}$ fabrics and a $\sigma$-clast (upper left K-feldspar) in mylonite from the Donau shear zone (sample 128) indicate top-right (i.e., dextral) sense of shear. c - High-temperature dextral shearing (S-C fabrics) results in growth of cordierite and sillimanite in deformed Weinsberg granite. Kasbach quarry, Loc. 567. d - Recrystallisation $(R)$ along fractures in, and along boundaries of, plagioclase suggests deformation and recovery after fracturing at elevated strain rate and under lower amphibolite-facies $P-T$ conditions. Foam textures in quartz $(F)$ support post-kinematic annealing and static recrystallisation. Sample 4032; Rodl shear zone. e - Recrystallised K-feldspar and $\mathbf{f}$ - recrystallised quartz, undulose extinction and subgrain formation in amphibole (arrow) suggest amphibolite-facies deformation in sample 252, facilitating the reseting of the Ar isotope system. 
Czech Republic and eastern Bavaria. Its prolonged intrusion history spans over c. 30 Ma but the main plutonic activity producing $80 \%$ of the batholith has been dated at 331-323 Ma (Gerdes et al. 2003). This time interval is specifically valid for the various types of the Weinsberg granite, the largest component of the batholith and the pluton which is most relevant to the current study. Along the eastern margin of the orogen the emplacement of the batholith was coeval with retrograde cooling of the country rock to the greenschist-facies temperatures and further decompression between $\sim 333 \mathrm{Ma}$ and $\sim 320 \mathrm{Ma}$ (Büttner and Kruhl 1997). At this stage the tectonic transport of Variscan units onto the eastern foreland graded into widespread NW-SE extensional tectonics $\left(\mathrm{D}_{3}\right.$ in Fritz and Neubauer 1993 and in Büttner and Kruhl 1997).

The Mühlzone is located at the south-western margin of the Bohemian Massif. Bound by the dextral Donau and Pfahl shear zones and the sinistral Rodl shear zone it exposes a crustal level that at Viséan times was deeper than other currently exposed parts of the southern Bohemian Massif. Along the eastern margin of the batholith the Weinsberg granite intruded at a depth corresponding to $300 \mathrm{MPa}$ (Büttner and Kruhl 1997) whereas the synintrusive pressure in the Mühlzone ranged between 380 $\mathrm{MPa}$ and $500 \mathrm{MPa}\left(\mathrm{D}_{2}\right.$ in Büttner 1999). Apart from rare and poorly exposed pre-intrusive structures $\left(\mathrm{D}_{1}\right.$ in Büttner 1999) the geological record in the Mühlzone starts with the emplacement of the Weinsberg granite $(\sim 331-323$ Ma, Finger et al. 2003; Gerdes et al. 2003). At this time the eastern margin of the orogen underwent greenschist facies extension ( $D_{3}$ in Büttner and Kruhl 1997).

During the emplacement of the Weinsberg granite in the Mühlzone, its country rocks, essentially biotite-plagioclase gneisses and possibly intercalated amphibolites, were close to their metamorphic peak (326-321 Ma; Büttner 1999; Kalt et al. 2000; Gerdes et al. 2006). Due to additional heat and fluid supply from the intruding Weinsberg magma, the country rocks underwent largescale diatexis forming the in situ Schlieren granite (Finger and Clemens 1995), which commonly forms a mantle around the Weinsberg Pluton (Fig. 1b). Textures and structures in both granites are similar (Finger 1986; Büttner 1999), showing essentially fabrics of their magmatic stage (Fig. 2a). In contrast to the Weinsberg granite, the Schlieren granite contains magmatic amphibole forming 2-4 $\mathrm{mm}$ large euhedral phenocrysts which have been used for $P-T$ analysis (Büttner 1999) and ${ }^{40} \mathrm{Ar} /{ }^{39} \mathrm{Ar}$ age dating (this study). Less or not anatectic equivalents of the Schlieren granite are plagioclase-biotite gneisses, commonly referred to as Perlgneis, which are present essentially along the Danube river (Fig. 1b; Finger 1986; Büttner 1999).

The intruding Weinsberg granite and the in situ Schlieren granite were affected by regional non-penetrative deformation forming a sub-horizontal magmatic foliation and a generally SE-NW trending lineation. Magmatic S-C fabrics, referred to as $\mathrm{D}_{2}$ (Büttner 1999), indicate hanging-wall tectonic transport to the south-east. This transport was referred to as low-angle thrusting (Büttner 1999). However, considering the almost horizontal orientation of the transport lineation and the shallow dip of the magmatic foliation (Fig. 3a), the $\mathrm{D}_{2}$ displacement cannot be interpreted as a contribution to crustal thickening. Solid state S-C and C' fabrics in the Perlgneis show a similar orientation, suggesting that plutons and country rocks were affected by the same kinematic event (Fig. 3a). Using magmatic amphibole and plagioclase from the Schlieren granite, the $P-T$ conditions of magma solidification have been determined as $\sim 380-500 \mathrm{MPa}$ and $700{ }^{\circ} \mathrm{C}$ (Büttner 1999). Various fine-grained granites (Fig. 1b; e.g., Mauthausen and Haibach type) intruded the crust after $\mathrm{D}_{2}$, between 319 and $315 \mathrm{Ma}$ (Gerdes et al. 2003).

During the late stage of granite solidification the subhorizontal $\mathrm{D}_{2}$ shear system became inactive and was, after a rarely developed transitional stage between magmatic and solid state flow (Büttner 1999), replaced by the conjugated ductile $\mathrm{D}_{3}$ shear zones that form the margins of the Mühlzone (e.g., Handler et al. 1991; Brandmayr et al. 1995, 1997). The highest temperature ductile deformation increment is seen in cordierite-sillimanite-muscovite bearing mylonites of the Pfahl shear zone which formed at retrograde $P-T$ conditions but still close to those obtained for the Schlieren granite's solidification $(\sim 370$ $\mathrm{MPa} / 675^{\circ} \mathrm{C}$; Büttner 1999). Although the large-scale map (Frasl et al. 1965) shows fine-grained granites at the location of this mylonite (Loc. 567 in Fig. 1b) the more likely protolith is Weinsberg granite which is exposed nearby, outside the shear zone.

Continuous ductile shearing during crustal cooling produced deformation increments formed under middle and lower amphibolite- and, locally, upper greenschistfacies conditions. Temperatures of deformation have been determined using muscovite-biotite thermobarometry and temperature-sensitive mineral assemblages and microfabrics. More details can be found in Handler et al. (1991), Brandmayr et al. $(1995,1997)$ and Büttner (1999). An age bracket of 288-281 Ma for greenschistfacies deformation has been suggested by Brandmayr et al. (1995) on the basis of muscovite ${ }^{40} \mathrm{Ar}{ }^{39} \mathrm{Ar}$ data. In a recent study, Siebel et al. (2005) have suggested initiation of ductile shearing along the Pfahl shear zone in Bavaria (about $70 \mathrm{~km}$ north-east of the study area) as early as $334 \pm 3 \mathrm{Ma}$ on the basis of $\mathrm{Pb}-\mathrm{Pb}$ zircon evaporation ages. This predates the thermal peak of metamorphism (321-326 Ma; U-Pb zircon ages, Kalt et al. 2000; Gerdes et al. 2006). However, no mylonites along the Pfahl show assemblages characteristic of the regional thermal peak 


\section{$D_{2}$ and $D_{3}$ macrofabric orientation}

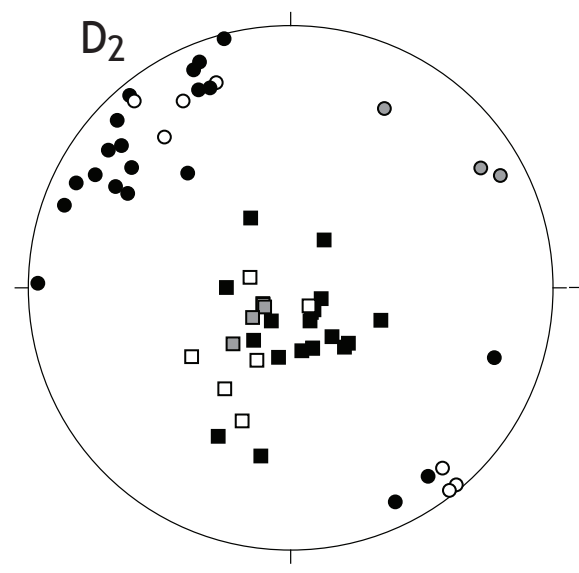

White: Perlgneis

Black: Weinsberg and Schlieren granites Grey: Weinsberg granite near St. Martin

a

Fig. 3 Orientation of macrofabrics used for palaeo-stress determination. Squares: poles to planes; circles: magmatic lineation in the Weinsberg and Schlieren granites and stretching lineation in the Perlgneis and $\mathrm{D}_{3}$ mylonites. $\mathbf{a}-\mathrm{D}_{2}$ fabrics in the Weinsberg and Schlieren granites and the Perlgneis. $\mathbf{b}$ - Shaded symbols illustrate the orientation of high-temperature mylonitic $\mathrm{D}_{3}$ fabrics in the Kasbach quarry (Loc. 567, Pfahl shear zone). $\mathbf{c}-\mathrm{D}_{3}$ fabrics from the sinistral Rodl shear zone.

(Crd-Sill-high Ti Bt \pm Spl, but no Ms; Büttner 1997). In all shear zones muscovite is present and sillimanite is rare, indicating retrograde shearing. High-temperature mylonites in the Pfahl shear zone probably benefited from heat supplied by the Weinsberg granite, from which they formed (Loc. 567, Fig. 2c).

\section{Magmatic and solid-state shearing in the Mühlzone}

For stress field estimations 78 foliation/transport lineation pairs from 36 locations within granites and the shear zones have been analysed (Fig. 1b), partly using previously published data (Büttner 1999). In all investigated locations shear sense indicators are present. Within the Weinsberg and Schlieren granites euhedral feldspar, isometric or irregularly shaped coarse-grained quartz, the absence of recrystallisation or other evidence of significant solid-state deformation (Fig. 2a), indicate the formation of the subhorizontal $\mathrm{D}_{2}$ shear fabrics by magmatic flow (e.g., Paterson et al. 1989; Vernon 2000). Titaniumrich biotite, sillimanite and occasional cordierite indicate amphibolite-facies conditions in the Perlgneis. The $\mathrm{D}_{2}$ foliation in the granites and the Perlgneis has a variable and generally shallow dip, apart from few moderately NNE dipping foliation planes (Fig. 3 in Büttner 1999). The magmatic lineation, defined by long axes of K-feldspar phenocrysts, plunges shallowly to the north-west.
Magmatic S-C fabrics indicate SE hangingwall transport $\left(D_{2}\right.$; Büttner 1999). Data from the two granites are indistinguishable. Occasionally the magmatic foliation is absent, and well developed lineations suggest prolate $\mathrm{D}_{2}$ strain. Near St. Martin (Fig. 1b) syn-magmatic $\mathrm{D}_{2}$ shearing led to southwest-directed hangingwall transport along subhorizontal shear planes (grey symbols in Fig. 3a).

The dextral Donau and Pfahl $\mathrm{D}_{3}$ shear zones (Figs 2b, c) show evidence of tectonic transport along moderately to steeply north-east dipping mylonitic foliation planes and shallowly south-east plunging stretching lineations (Fig. 3b), indicating dominant strike-slip with a small component of normal-slip displacement. In locality 567 of the Pfahl shear zone (Fig. 1b) high-temperature deformation, indicated by synkinematic growth of sillimanite and cordierite (Fig. 2c), has produced structures different than in other places along this shear zone. The foliation is more northerly dipping and the stretching lineation plunges northwest (graded symbols in Fig. 3b), plotting closely to the position of magmatic $\mathrm{D}_{2}$ lineations (Fig. 3a). Tectonic transport in the sinistral Rodl shear zone occurred along steep northeast-southwest striking foliation planes and subhorizontal stretching lineations (Fig. 3c). Foliation poles and lineations plotting close to the periphery of the stereonet suggest strike-slip displacement without the small normal-slip component that is seen in the dextral shear zones. The uniform orientation of $\mathrm{D}_{3}$ shear zones along strike, regardless of the lithology that is crosscut, suggests low rheological contrasts during their formation. 
Microfabrics in the ductile $\mathrm{D}_{3}$ shear zones (i.e., Pfahl, Rodl and Donau) suggest deformation under amphibolite-facies conditions, indicating their coeval activity and conjugated nature. The most common temperaturesensitive microfabrics are recrystallised feldspar (Voll 1976) associated with efficient quartz recrystallisation and recovery in foam structures (Fig. 2d), syn-kinematic presence of sillimanite and, at one location in the Pfahl shear zone, growth of cordierite (Fig. 2c). Most data used for the determination of the $\mathrm{D}_{3}$ palaeo-stress field were taken from such locations. A minority comes from localities that suggest deformation under upper greenschist-facies conditions, indicated by undulose extinction of plagioclase, kinking and deformation twins in feldspar, quartz recrystallisation, but absence of feldspar recrystallisation. As quartz is the most abundant phase in the investigated rocks, ductile flow can be safely assumed. Hence, von Mise's Law applies to the determination of the palaeo-stress field orientation.

\section{Inferred palaeo-stress field variations}

A crucial factor for the determination of the palaeo-stress field orientation is the proportion of simple and pure shear flow during ductile deformation. For both deformation phases, $\mathrm{D}_{2}$ and $\mathrm{D}_{3}$, a kinematic vorticity number close to 1 (i.e., dominant simple-shear flow) is likely. This assumption is supported by the following observations and considerations. (i) A high proportion of pure shear flow in general shear environment would produce some shear sense indicators showing the opposite shear sense than the majority of the indicators (e.g., Passchier and Trouw 2005). Such indicators do not occur in the $\mathrm{D}_{2}$ or $\mathrm{D}_{3}$ fabrics (Büttner 1999). (ii) The magmatic shear fabrics are developed in large granite plutons which, specifically in the Weinsberg granite, lack pre-existing foliations. Both the Weinsberg and the Schlieren granites contained a significant melt proportion that allowed solid phases to rotate freely and to align with the $\mathrm{D}_{2}$ foliation (Büttner 1999). The absence of boundary conditions (e.g., dyke walls or other confining surfaces), allowed the development of shear planes along the surface of maximum shear stress, which is orientated at $45^{\circ}$ to $\sigma_{1}$ and $\sigma_{3}$. Displacement occurs perpendicular to $\sigma_{2}$, defining the orientation of the transport lineation. This orientation of stress and strain is equivalent to simple shear. (iii) The conjugated $\mathrm{D}_{3}$ strike slip zones intersect at $90^{\circ}$, which indicates that $\sigma_{1}$ has an approximately N-S trend with a shallow plunge, bisecting the shear zones. This implies simple shear along the $\mathrm{D}_{3}$ shear zones. A significant component of pure shear in general shear flow should cause an intersection angle smaller than $90^{\circ}$ or, in case of pure shear flow, no formation of conjugate shear zones. (iv) During $\mathrm{D}_{3}$, granites and migmatites were converted to mica-rich schistose mylonites, suggesting intense pressure solution. This may support a high proportion of simple shear because the $\mathrm{C}$ plane in simple shear is static and remains in the position of maximum shear stress throughout the deformation event (Passchier and Trouw 2005), maximising the intensity of pressure solution.

The orientation of palaeo-stress fields has been obtained stereographically from field data (Fig. 4). During homogenous deformation, $\sigma_{2}$ is located within the shear plane, at $90^{\circ}$ to the transport lineation (Fig. 4a). In stereographic projection the minimum and maximum principal stresses plot on a great circle to which $\sigma_{2}$ is the pole, and the shear sense vectors along the foliation plane allow discriminating between $\sigma_{1}$ and $\sigma_{3}$. In simple shear mode, and according to von Mise's Law, ductile (and magmatic) flow forms shear zones in the orientation of the maximum shear stress. Therefore, an angle of internal friction of $45^{\circ}$ can be assumed, placing the position of $\sigma_{1}$ and $\sigma_{3}$ at this angle to the transport lineation.

The stress vector distribution obtained from magmatic fabrics in the Weinsberg and Schlieren granites forms clusters with average orientations of 147/32 $\left(\sigma_{1}\right), 052 / 12$ $\left(\sigma_{2}\right)$ and $303 / 56\left(\sigma_{3}\right.$; Tab. 1; Fig. 4b). According to the variable orientation of $\mathrm{D}_{2}$ structures the obtained stress fields show a relatively large scatter. In agreement with field evidence, the stress field with shallowly-plunging $\sigma_{1}$ and $\sigma_{2}$ vectors and steep $\sigma_{3}$ indicates southeast-directed $\mathrm{D}_{2}$ low-angle thrusting as the main component of dextral oblique slip. The stress field orientations obtained from the St. Martin exposures suggest $\sigma_{1}$ shallowly plunging to the southwest, subhorizontal NNW-SSE oriented $\sigma_{2}$, and $\sigma_{3}$ plunging steeply to the NE (grey symbols in Figs 3a, 4b).

Tab. 1 Average orientation of stress vectors during $\mathrm{D}_{2}$, and high- and moderate temperature $\mathrm{D}_{3}$.

\begin{tabular}{lcccc}
\hline & $\mathrm{D}_{2}$ & $\mathrm{D}_{3}$ & $\mathrm{D}_{3}$ calculated $^{*}$ & high $-T \mathrm{D}_{3}^{* *}$ \\
\hline$\sigma_{1}$ & $147 / 32$ & $168 / 17$ & $169 / 19$ & $162 / 01$ \\
$\sigma_{2}$ & $052 / 12$ & $331 / 72$ & $332 / 72$ & $072 / 41$ \\
$\sigma_{3}$ & $303 / 56$ & $76 / 03$ & $077 / 05$ & $253 / 49$ \\
\hline \\
"Calculated by anticlockwise rotation of $\mathrm{D}_{2}$ stress vectors by $76^{\circ}$ around \\
150/13. \\
" Kasbach quarry, Pfahl shear zone (Loc. 567, Fig. 1b).
\end{tabular}

The $\mathrm{D}_{3}$ stress field patterns obtained from the sinistral Rodl and the dextral Pfahl and Donau shear zones indicate similar orientation of the stress ellipsoid but different distribution of stress vectors compared to $\mathrm{D}_{2}$. Steep $\sigma_{2}$ vectors plotting close to the centre of the stereonet (Fig. 4c) reflect the main strike-slip component in the shear zones. Compared to $\mathrm{D}_{2}, \sigma_{1}$ shows minor clockwise rotation but is still in a NNW-SSW trending and shallowly plunging orientation. The $\sigma_{3}$ has a subhorizontal 


\section{Palaeo-stress estimations}

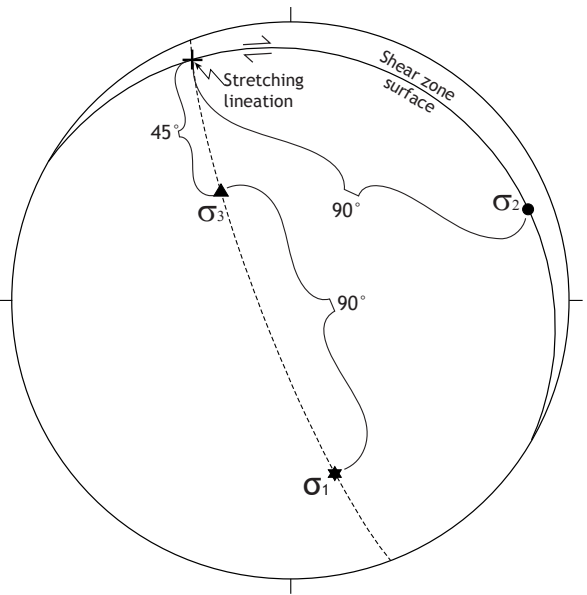

a) Method of paleo-stress estimation

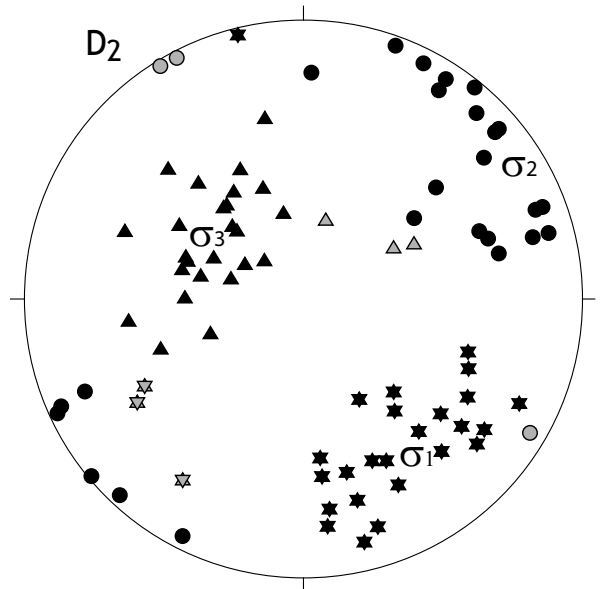

b) Black: palaeo-stress field orientation in Perlgneis and Weinsberg granite. Grey: Weinsberg granite near St. Martin.

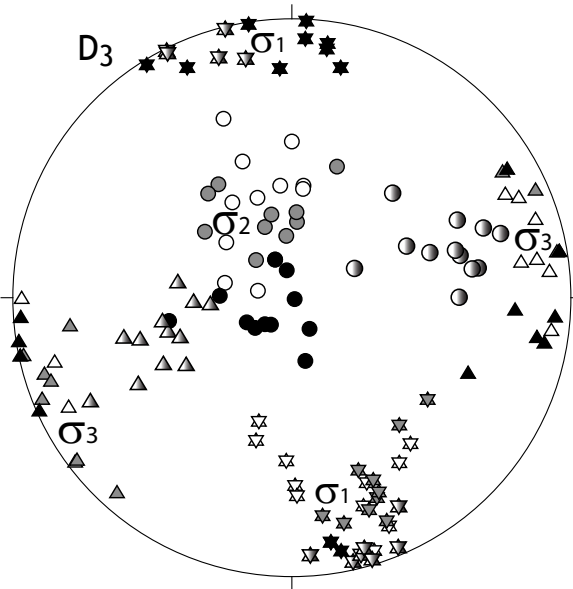

c) Black: palaeo-stress field orientation in the Rodl shear zone. Grey: Donau shear zone. White: Pfahl shear zone. Shaded: high- $T$ stage in the Pfahl shear zone.

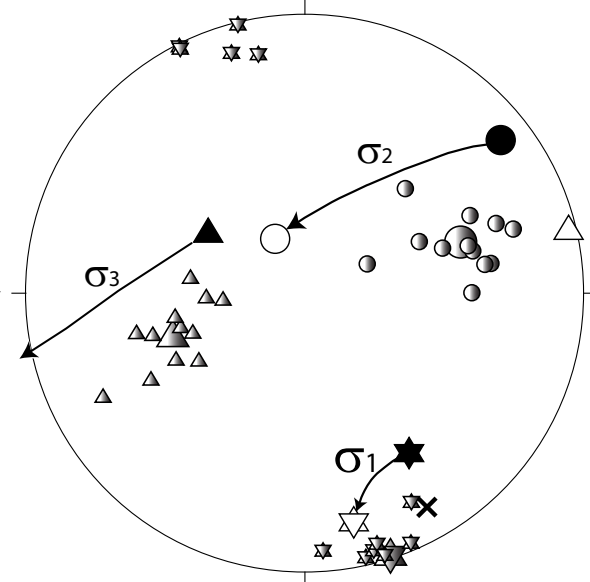

d) Large symbols: average values. Black: $D_{2}$. White: $D_{3}$. Shaded: average and individual stress orientations of the high- $T D_{3}$ stage in the Pfahl shear zone (Loc. 567).
Fig. 4 Method and results of palaeostress field determination. Stars: $\sigma_{1}$, circles: $\sigma_{2}$, triangles: $\sigma_{3}$. a) Foliation and lineation of a dextral thrust zone, plotted as great circle and cross, determine the position of $\sigma_{2}$ at $90^{\circ}$ off the lineation. The $\sigma_{1}$ and $\sigma_{3}$ plot on the great circle to which $\sigma_{2}$ is the pole, at $45^{\circ}$ to the transport lineation (von Mise's Law). More details can be found in the text and in Davis and Reynolds (1996). b) and c) Stress vector orientations determined from $\mathrm{D}_{2}$ and $\mathrm{D}_{3}$ structures. d) Rotation of average stress vectors during the transition from $\mathrm{D}_{2}$ to $\mathrm{D}_{3}$. Arrows indicate the possible rotation path assuming $76^{\circ}$ rotation around an axis oriented at 150/13 (cross). The stress vectors determined for Loc. 567 are vaguely compatible with this rotation, although they plot off the easiest possible rotation path.
ENE-WSW orientation. Average orientations of the stress vectors are given in Tab. 1. A significant variation is seen between stress fields obtained from high-temperature mylonites in location 567 and all other (lower-temperature) mylonites. The $\sigma_{1}$ vectors show the usual shallowly plunging SSE-NNW orientation, whereas $\sigma_{2}$ an $\sigma_{3}$ clusters are shifted away from typical $\mathrm{D}_{3}$ positions. The $\sigma_{2}$ vectors plunge moderately ENE and $\sigma_{3}$ moderately WSW (Tab. 1, shaded symbols in Fig. 4c-d).

\section{5. ${ }^{40} \mathrm{Ar}-{ }^{39} \mathrm{Ar}$ amphibole ages}

Supplementing U-Pb zircon data of Finger et al. (2003) and Gerdes et al. (2003) for the intrusive Weinsberg granite, ${ }^{40} \mathrm{Ar}-{ }^{39} \mathrm{Ar}$ amphibole ages have been obtained from four samples of the Schlieren granite. Euhedral magmatic amphibole crystals, 3-4 millimetres in size, were separated and analysed at the ARGONAUT lab of the Department of Geology at Salzburg University, Austria. Methods and analytical procedures of ${ }^{40} \mathrm{Ar}-{ }^{39} \mathrm{Ar}$ dating were given in Handler et al. (2004). The dated samples come from the same localities from which amphibole-plagioclase $P-T$ data were published previously (Büttner 1999). Three samples (574, 581, and 595) were taken at least $5 \mathrm{~km}$ away from major $\mathrm{D}_{3}$ shear zones; one sample (252) comes from the periphery of the Donau shear zone. Samples 574, 581 and 595 show almost undeformed magmatic fabrics (Fig. 2a). Chessboard patterns in quartz (Kruhl 1996) and minor bending of twin 
lamellae in plagioclase suggest minor deformation at high temperature which is interpreted as related to the solidification stage of the Schlieren granite. In sample 252, more intense deformation is indicated by recrystallisation of K-feldspar, quartz (Fig. 2e-f), biotite and plagioclase. Amphibole shows undulose extinction and formation of subgrains (Fig. 2f). Foam structures in quartz suggest recovery and static recrystallisation. Recrystallisation of feldspar indicates deformation at amphibolite facies temperatures (Voll 1976). The three samples from the interior of the Mühlzone produced ${ }^{40} \mathrm{Ar} /{ }^{39} \mathrm{Ar}$ amphibole plateau ages of $c$. $329 \mathrm{Ma}$ with individual uncertainties of approximately $\pm 11 \mathrm{Ma}(2 \sigma$; Fig. 5a-c, Tab. 2). Amphibole from the sheared sample 252 produced a younger age (308 $\pm 11 \mathrm{Ma}$; Fig. 5 d), postdating the regional hightemperature/low-pressure event (see below) but predating cooling ages obtained from white mica from the Donau shear zone and the Haibach granite outside the shear zone (288.5 \pm 0.6 and $287.3 \pm 0.6 \mathrm{Ma}$, respectively; Brandmayr et al. 1995).

The regional high-temperature/low-pressure metamorphism, closely related to partial melting and batholith formation, has been dated using the U-Pb isotopic system of zircon and monazite. Kalt et al. (2000) suggested that the thermal peak and anatectic melt formation occurred in migmatites of the SE Bayerischer Wald between 326 and $323 \mathrm{Ma}$ (U-Pb zircon data). These data were confirmed by monazite ages of 321-326 Ma obtained from migmatites from the Mühlzone and SE Bavaria (Gerdes et al. 2006) and by U-Pb SHRIMP ages indicating metamorphic zircon growth at $319 \pm 5 \mathrm{Ma}$ and $316 \pm 10 \mathrm{Ma}$ (Teipel et al. 2004). Within the errors the ${ }^{40} \mathrm{Ar} /{ }^{39} \mathrm{Ar}$ amphibole ages from the samples 574, 581, and 595 correlate with the previouslyestablished timing of the regional high-temperature event and the intrusion of the Weinsberg granite in the Mühlzone rather than with slow crustal cooling below the commonly accepted closure temperature of the amphibole Ar isotopic system ( 500-600 ${ }^{\circ} \mathrm{C}$; Dahl 1996). They therefore may provide a time constraint for the formation of the Schlieren granite, which was genetically related to the intrusion of the Weinsberg granite (Finger and Clemens 1995; Büttner 1999). Sample 252 experienced ductile deformation at amphibolite-facies temperature, which has influenced the Ar isotope systematics and has partly or totally reset the age.

\section{Discussion and conclusions}

High-temperature mylonitisation seen at Loc. 567 in the Pfahl shear zone is the highest temperature increment of $\mathrm{D}_{3}$ solid state mylonitisation that occurred shortly after the solidification of the Weinsberg and Schlieren granites. $\mathrm{U}-\mathrm{Pb}$ zircon and ${ }^{40} \mathrm{Ar} /{ }^{39} \mathrm{Ar}$ amphibole ages suggest that this stage in the Mühlzone was reached in the late Viséan
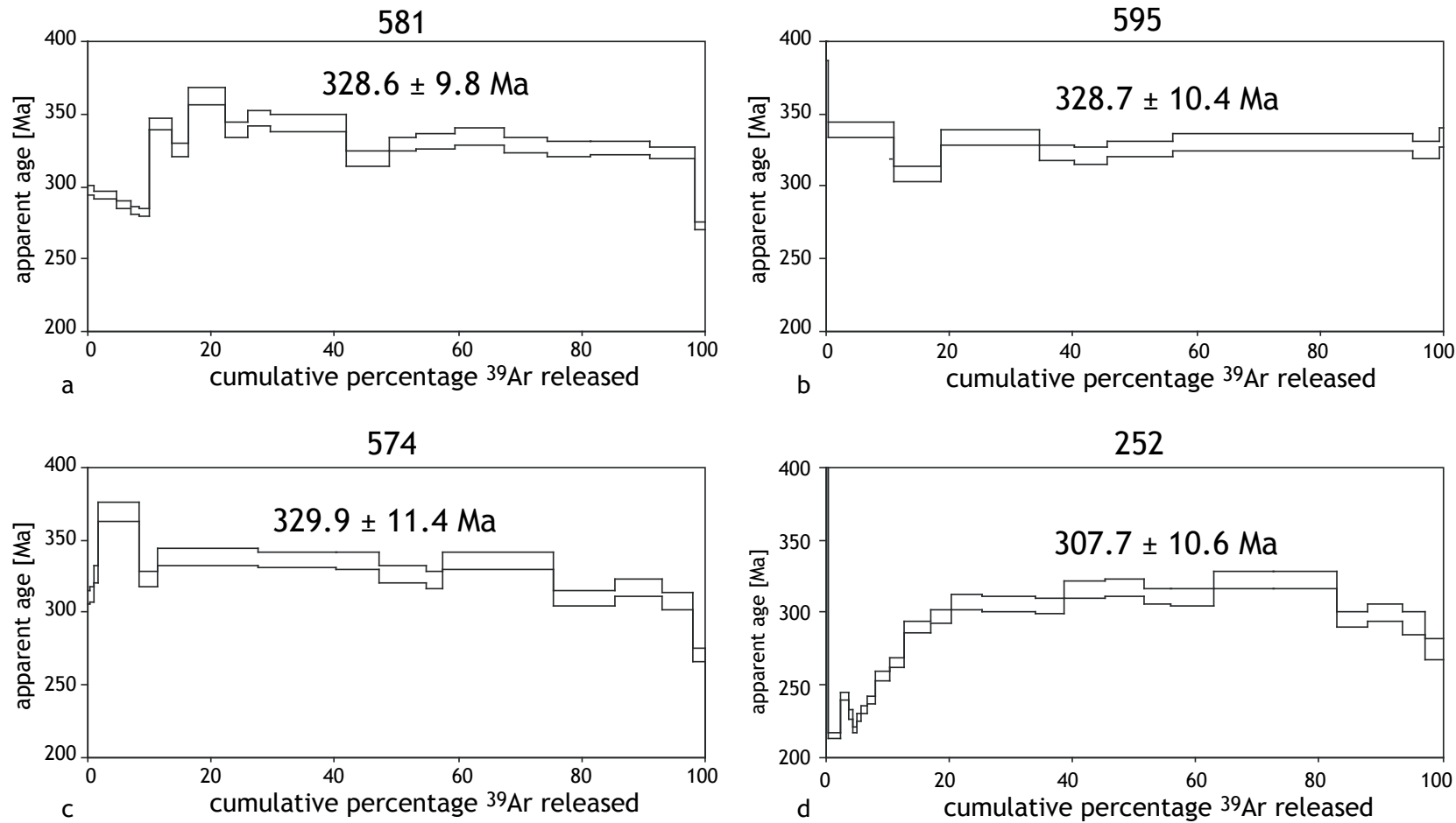

Fig. $5{ }^{40} \mathrm{Ar}-{ }^{39} \mathrm{Ar}$ laser step heating age spectra of magmatic amphibole from four Schlieren granite samples. Sample locations are shown in Figure 1b. All uncertainties are reported as $\pm 2 \sigma$, the width of the symbols represents $\pm 1 \sigma$. The corresponding analytical data are presented in Tab. 2 . 
Tab. 2 Ar-analytical data from multi-grain ${ }^{40} \mathrm{Ar} /{ }^{39} \mathrm{Ar}$ incremental heating analysis on amphibole from the Mühlzone, Upper Austria. Uncertainties are $1 \sigma$ inter-laboratory.

\begin{tabular}{|c|c|c|c|c|c|c|c|}
\hline $\begin{array}{l}\text { Sample: } \\
\text { J-Value: }\end{array}$ & $\begin{array}{l}581 \\
0.008239\end{array}$ & & & & & & \\
\hline Increment & ${ }^{36} \mathrm{Ar} /{ }^{39} \mathrm{Ar}^{\mathrm{a}}$ & ${ }^{37} \mathrm{Ar} /{ }^{39} \mathrm{Ar}^{\mathrm{b}}$ & ${ }^{40} \mathrm{Ar} /{ }^{39} \mathrm{Ar}^{\mathrm{a}}$ & $\%{ }^{39} \mathrm{Ar}$ & $\% 0^{40} \mathrm{Ar}^{\mathrm{c}}$ & age & $1 \sigma$ \\
\hline 1 & 0.019250 & 1.802786 & 27.247838 & 1.24 & 79.12 & 296.9 & 3.7 \\
\hline 2 & 0.006828 & 0.200220 & 23.477602 & 3.47 & 91.41 & 293.6 & 2.7 \\
\hline 3 & 0.001984 & 0.209279 & 21.496417 & 2.38 & 97.27 & 286.6 & 2.7 \\
\hline 4 & 0.002169 & 0.228196 & 21.310047 & 1.45 & 96.99 & 283.6 & 2.7 \\
\hline 5 & 0.002347 & 0.417900 & 21.238412 & 1.60 & 96.73 & 282.3 & 2.7 \\
\hline 6 & 0.003217 & 2.541243 & 26.159330 & 3.78 & 96.37 & 343.4 & 4.5 \\
\hline 7 & 0.003937 & 2.457622 & 24.906150 & 2.62 & 95.33 & 325.1 & 4.4 \\
\hline 8 & 0.004367 & 3.794324 & 27.925008 & 5.90 & 95.38 & 362.5 & 5.9 \\
\hline 9 & 0.003703 & 3.095716 & 25.889899 & 3.58 & 95.77 & 339.0 & 5.1 \\
\hline 10 & 0.002642 & 3.288888 & 26.227451 & 3.55 & 97.02 & 347.3 & 5.3 \\
\hline 11 & 0.002649 & 3.856864 & 25.914957 & 12.47 & 96.98 & 344.1 & 5.9 \\
\hline 12 & 0.002552 & 3.371952 & 23.910878 & 6.93 & 96.85 & 319.0 & 5.2 \\
\hline 13 & 0.003061 & 3.320269 & 24.908456 & 4.32 & 96.37 & 329.5 & 5.2 \\
\hline 14 & 0.002552 & 3.689639 & 24.869432 & 6.30 & 96.97 & 331.4 & 5.6 \\
\hline 15 & 0.002877 & 3.714515 & 25.211106 & 7.83 & 96.63 & 334.4 & 5.7 \\
\hline 16 & 0.002768 & 3.740466 & 24.744083 & 6.98 & 96.69 & 329.1 & 5.7 \\
\hline 17 & 0.002586 & 3.203027 & 24.481920 & 6.87 & 96.88 & 325.8 & 5.1 \\
\hline 18 & 0.002483 & 2.960277 & 24.591778 & 9.66 & 97.02 & 327.2 & 4.9 \\
\hline 19 & 0.002531 & 2.498182 & 24.375006 & 7.57 & 96.93 & 323.7 & 4.4 \\
\hline 20 & 0.010135 & 0.464611 & 22.762252 & 1.51 & 86.84 & 272.4 & 2.7 \\
\hline Total & 0.003281 & 3.000804 & 24.936608 & 100.00 & 96.11 & 328.6 & 4.9 \\
\hline
\end{tabular}

${ }^{\text {a }}$ measured; b corrected for post-irradiation decay of ${ }^{37} \mathrm{Ar}(35.1$ days half-life $) ;{ }^{\mathrm{c}}\left({ }^{40} \mathrm{Ar}_{\text {tot }}-{ }^{36} \mathrm{Ar}_{\mathrm{atm}} \times 295.5\right) /{ }^{40} \mathrm{Ar}_{\text {tot }}$

$(\sim 325 \mathrm{Ma})$. At this point the kinematic pattern in the Mühlzone changed from subhorizontal $\mathrm{D}_{2}$ displacement to conjugate $\mathrm{D}_{3}$ strike-slip shearing, converting subhorizontal orogen-parallel flow to lateral escape tectonics. Compared to the rather penetrative $\mathrm{D}_{2}$ stage, strain in the solid state was localized in tens to up to $c .500$ meter wide steep shear zones, leaving the crust between the shear zones largely unaffected. During cooling of the crust, periodically or continuously, $\mathrm{D}_{3}$ shearing continued until the Permian with possible brittle reactivation during the Alpine event (Handler et al. 1991; Brandmayr et al. 1995 , 1997). At Pennsylvanian time (308 $\pm 11 \mathrm{Ma})$ the temperature was still high enough for deformation-assisted resetting of the Ar isotopic system, which appears to require at least lower amphibolite-facies conditions (Dahl 1996).

The transition from subhorizontal magmatic to the steep solid-state shearing was related to changes in the stress field orientation. Calculated average stress vector positions are considered to approximate the stress field orientations for the $\mathrm{D}_{2}$ and $\mathrm{D}_{3}$ stages. Average $\mathrm{D}_{2}$ stress vectors (Tab. 1, Fig. 4d) have been calculated using magmatic structures from the Schlieren and Weinsberg granites as well as high-temperature solid-state defor- mation structures from the Perlgneis. The $\mathrm{D}_{3}$ stress field (Tab. 1) has been determined using data from exposures showing evidence for lower amphibolite- and upper greenschist-facies deformation temperatures, excluding the high-temperature mylonites from the Pfahl shear zone (Kasbach quarry, Loc. 567, Fig. 1b). Hence, the $\mathrm{D}_{3}$ stress vectors should represent the stress field orientation for the crust at the cooling stage (approximately $500-600{ }^{\circ} \mathrm{C}$ ). During $\mathrm{D}_{2}$ and $\mathrm{D}_{3}$ the $\sigma_{1}$ stress vector remained in a shallowly south-southeast plunging orientation with a small variation of about $25^{\circ}$ (Fig. 4d). At the $\mathrm{D}_{3}$ stage, $\sigma_{2}$ had attained a new position $(\sim 331 / 72)$, about $20^{\circ}$ away from the previous $\mathrm{D}_{2}$ position of $\sigma_{3}$, while $\mathrm{D}_{3}$ 's $\sigma_{3}$ is about $25^{\circ}$ away from $\mathrm{D}_{2}$ 's $\sigma_{2}$ (Fig. 4d). Hence, the intermediate and minimum stress vectors almost swapped positions during the transition from magmatic to solid-state deformation, while $\sigma_{1}$ remained approximately constant. The rotation of the stress field can be described by $76^{\circ}$ anticlockwise rotation of the $\mathrm{D}_{2}$ stresses around an axis oriented at $150 / 13$, which is close to all calculated average $\sigma_{1}$ vectors (Tab. 1, Fig. 4d).

The position of $\sigma_{2}$ and $\sigma_{3}$ vectors obtained from the high-temperature solid-state structures (Locality 567 of the Pfahl shear zone) is roughly between the areas oc- 
Tab. 2 Continued

\begin{tabular}{|c|c|c|c|c|c|c|c|}
\hline $\begin{array}{l}\text { Sample: } \\
\text { J-Value: }\end{array}$ & $\begin{array}{l}595 \\
0.008279\end{array}$ & & & & & & \\
\hline Increment & ${ }^{36} \mathrm{Ar} /{ }^{39} \mathrm{Ar}^{\mathrm{a}}$ & ${ }^{37} \mathrm{Ar} /{ }^{39} \mathrm{Ar}^{\mathrm{b}}$ & ${ }^{40} \mathrm{Ar} /{ }^{39} \mathrm{Ar}^{\mathrm{a}}$ & ${ }^{39} \mathrm{Ar}$ & $\%{ }^{40} \mathrm{Ar}^{\mathrm{c}}$ & age & $1 \sigma$ \\
\hline 1 & 0.111503 & 5.007973 & 71.817376 & 0.05 & 54.12 & 509.4 & 32.8 \\
\hline 2 & 0.055687 & 2.893944 & 45.618935 & 0.37 & 63.93 & 393.6 & 7.1 \\
\hline 3 & 0.004847 & 3.835417 & 26.016784 & 10.77 & 94.49 & 338.8 & 5.9 \\
\hline 4 & 0.002588 & 3.598972 & 22.943436 & 7.59 & 96.67 & 308.4 & 5.5 \\
\hline 5 & 0.002561 & 3.930603 & 24.911702 & 15.93 & 96.96 & 333.6 & 5.9 \\
\hline 6 & 0.003544 & 3.600588 & 24.389781 & 5.47 & 95.71 & 323.1 & 5.5 \\
\hline 7 & 0.004784 & 3.900284 & 24.585394 & 5.62 & 94.25 & 321.3 & 5.9 \\
\hline 8 & 0.003957 & 3.672088 & 24.700893 & 10.49 & 95.27 & 325.5 & 5.6 \\
\hline 9 & 0.002326 & 3.751026 & 24.561120 & 38.70 & 97.20 & 329.9 & 5.7 \\
\hline 10 & 0.011877 & 3.900541 & 26.997542 & 4.29 & 87.00 & 325.3 & 5.9 \\
\hline 11 & 0.108885 & 3.949358 & 56.357008 & 0.72 & 42.91 & 334.0 & 6.6 \\
\hline Total & 0.004462 & 3.774390 & 25.093442 & 100.00 & 94.75 & 328.7 & 5.7 \\
\hline $\begin{array}{l}\text { Sample: } \\
\text { J-Value: }\end{array}$ & $\begin{array}{l}574 \\
0.008200\end{array}$ & & & & & & \\
\hline Increment & ${ }^{36} \mathrm{Ar} /{ }^{39} \mathrm{Ar}^{\mathrm{a}}$ & ${ }^{37} \mathrm{Ar} /{ }^{39} \mathrm{Ar}^{\mathrm{b}}$ & ${ }^{40} \mathrm{Ar} /{ }^{39} \mathrm{Ar}^{\mathrm{a}}$ & ${ }^{39} \mathrm{Ar}$ & $\%{ }^{40} \mathrm{Ar}^{\mathrm{c}}$ & age & $1 \sigma$ \\
\hline 1 & 0.031964 & 1.957199 & 32.189600 & 0.49 & 70.66 & 310.7 & 4.6 \\
\hline 2 & 0.023940 & 2.732953 & 29.871475 & 0.48 & 76.32 & 312.3 & 4.9 \\
\hline 3 & 0.026101 & 3.797464 & 31.481727 & 0.74 & 75.50 & 325.8 & 5.9 \\
\hline 4 & 0.014148 & 4.445182 & 31.386822 & 6.76 & 86.68 & 368.7 & 6.6 \\
\hline 5 & 0.005132 & 3.609173 & 25.056667 & 3.05 & 93.95 & 322.7 & 5.5 \\
\hline 6 & 0.003620 & 3.778914 & 25.835665 & 16.17 & 95.86 & 338.1 & 5.8 \\
\hline 7 & 0.003181 & 3.843868 & 25.542231 & 12.40 & 96.32 & 336.1 & 5.8 \\
\hline 8 & 0.003833 & 3.789958 & 25.707529 & 7.22 & 95.59 & 335.7 & 5.8 \\
\hline 9 & 0.004163 & 3.747910 & 25.052026 & 7.51 & 95.09 & 326.4 & 5.7 \\
\hline 10 & 0.007164 & 3.810608 & 25.616135 & 2.67 & 91.74 & 322.4 & 5.7 \\
\hline 11 & 0.003409 & 3.833396 & 25.557297 & 18.14 & 96.06 & 335.5 & 5.8 \\
\hline 12 & 0.001978 & 3.623973 & 23.073642 & 9.83 & 97.47 & 309.6 & 5.5 \\
\hline 13 & 0.002709 & 3.829907 & 23.861541 & 7.71 & 96.65 & 317.0 & 5.7 \\
\hline 14 & 0.004212 & 3.935740 & 23.542112 & 4.63 & 94.71 & 307.6 & 5.8 \\
\hline 15 & 0.013571 & 2.966094 & 23.513711 & 2.19 & 82.95 & 271.1 & 4.6 \\
\hline Total & 0.004852 & 3.806075 & 25.537575 & 100.00 & 94.39 & 329.9 & 5.7 \\
\hline
\end{tabular}

a measured; b corrected for post-irradiation decay of ${ }^{37} \mathrm{Ar}(35.1$ days half-life $) ;{ }^{\mathrm{c}}\left({ }^{40} \mathrm{Ar}_{\text {tot }}-{ }^{36} \mathrm{Ar}_{\mathrm{atm}} \times 295.5\right) /{ }^{40} \mathrm{Ar}_{\text {tot }}$

cupied by other $\sigma_{2}$ and $\sigma_{3}$ stresses (Figs $4 \mathrm{c}-\mathrm{d}$ ). Although individual and average stress vectors of that stage do not exactly plot along the calculated rotation paths of the regional $\sigma_{2}$ and $\sigma_{3}$, the high-temperature shearing may record a transient stage of continuous stress field rotation.

The rotation of the stress field, and hence the orientation of structures produced, correlates closely with the disappearance of the intrusive and anatectic melt in the Mühlzone ( $\sim 325 \mathrm{Ma})$. The instant change in stress field orientation is evident from the lack of a significant solidstate overprint along $\mathrm{D}_{2}$ shear fabrics in the granites, and from the rare occurrence of fabrics formed at the transi- tional stage from magmatic to solid-state flow. The shear strength of the granites can be expected to have increased significantly during solidification. This led to increasing differential stress in the crust but should not have caused rotation of the stress field. An increase in differential stress during $\mathrm{D}_{3}$ is supported by common brittle-ductile deformation at amphibolite-facies temperatures, suggesting high strain rates in mylonites of the Rodl shear zone (Fig. 2d).

The variation of stress vector orientations is interpreted as reflecting variations in Viséan tectonic processes along the southern Variscan suture zone after continent collision. $\sigma_{3}$ changed its orientation from subvertical to 
Tab. 2 Continued

\begin{tabular}{|c|c|c|c|c|c|c|c|}
\hline $\begin{array}{l}\text { Sample: } \\
\text { J-Value: }\end{array}$ & $\begin{array}{l}252 \\
0.008161\end{array}$ & & & & & & \\
\hline Increment & ${ }^{36} \mathrm{Ar}{ }^{39} \mathrm{Ar}^{\mathrm{a}}$ & ${ }^{37} \mathrm{Ar} r{ }^{39} \mathrm{Ar}^{\mathrm{b}}$ & ${ }^{40} \mathrm{Ar} /{ }^{39} \mathrm{Ar}^{\mathrm{a}}$ & ${ }^{0}{ }^{39} \mathrm{Ar}$ & $\%{ }^{40} \mathrm{Ar}^{\mathrm{c}}$ & age & $1 \sigma$ \\
\hline 1 & 2.304868 & 3.631018 & 984.938893 & 0.14 & 30.85 & 2253.9 & 19.3 \\
\hline 2 & 0.345370 & 2.711973 & 185.454284 & 0.40 & 44.97 & 939.7 & 8.7 \\
\hline 3 & 0.049508 & 0.968410 & 30.072479 & 1.74 & 51.35 & 215.0 & 2.5 \\
\hline 4 & 0.033853 & 0.498379 & 27.563276 & 1.50 & 63.71 & 241.9 & 2.5 \\
\hline 5 & 0.009684 & 0.255434 & 19.481779 & 0.54 & 85.31 & 229.4 & 2.8 \\
\hline 6 & 0.010313 & 0.291071 & 18.875177 & 0.89 & 83.85 & 219.1 & 2.3 \\
\hline 7 & 0.005552 & 0.356514 & 18.073705 & 0.73 & 90.92 & 227.1 & 2.4 \\
\hline 8 & 0.007169 & 0.376399 & 18.953213 & 0.89 & 88.82 & 232.3 & 2.4 \\
\hline 9 & 0.007453 & 0.656965 & 19.578321 & 1.13 & 88.75 & 239.7 & 2.5 \\
\hline 10 & 0.007635 & 1.014282 & 20.868628 & 2.42 & 89.19 & 256.0 & 2.7 \\
\hline 11 & 0.003867 & 1.561120 & 20.435385 & 2.38 & 94.41 & 265.4 & 3.2 \\
\hline 12 & 0.003680 & 2.742937 & 22.168116 & 4.33 & 95.09 & 289.5 & 4.4 \\
\hline 13 & 0.002979 & 2.728384 & 22.559491 & 3.47 & 96.10 & 297.0 & 4.5 \\
\hline 14 & 0.003448 & 3.292261 & 23.414175 & 4.99 & 95.65 & 306.7 & 5.1 \\
\hline 15 & 0.003080 & 3.694948 & 23.150770 & 8.28 & 96.07 & 305.3 & 5.5 \\
\hline 16 & 0.003197 & 3.255786 & 23.147184 & 4.85 & 95.92 & 304.2 & 5.0 \\
\hline 17 & 0.003219 & 3.918075 & 24.031310 & 6.53 & 96.04 & 316.0 & 5.8 \\
\hline 18 & 0.003482 & 4.091728 & 24.209963 & 6.43 & 95.75 & 317.5 & 6.0 \\
\hline 19 & 0.004314 & 3.561869 & 23.962607 & 4.18 & 94.68 & 310.7 & 5.4 \\
\hline 20 & 0.003851 & 3.967022 & 23.714682 & 7.13 & 95.20 & 309.8 & 5.8 \\
\hline 21 & 0.003661 & 4.281687 & 24.644078 & 9.64 & 95.61 & 322.4 & 6.2 \\
\hline 22 & 0.003799 & 4.301438 & 24.682244 & 10.14 & 95.45 & 322.4 & 6.2 \\
\hline 23 & 0.002599 & 3.624678 & 22.161119 & 4.93 & 96.54 & 294.6 & 5.4 \\
\hline 24 & 0.003303 & 4.066937 & 22.691900 & 5.74 & 95.70 & 299.2 & 5.9 \\
\hline 25 & 0.005134 & 5.411511 & 22.558229 & 3.87 & 93.27 & 292.5 & 7.4 \\
\hline 26 & 0.006687 & 4.956854 & 21.634577 & 2.74 & 90.87 & 274.4 & 6.9 \\
\hline Total & 0.009659 & 3.510196 & 25.308307 & 100.00 & 88.72 & 307.7 & 5.3 \\
\hline
\end{tabular}

${ }^{\mathrm{a}}$ measured; ${ }^{\mathrm{b}}$ corrected for post-irradiation decay of ${ }^{37} \mathrm{Ar}(35.1$ days half-life $) ;{ }^{\mathrm{c}}\left({ }^{40} \mathrm{Ar}_{\text {tot }}-{ }^{36} \mathrm{Ar}_{\mathrm{atm}} \times 295.5\right) /{ }^{40} \mathrm{Ar}_{\text {tot }}$

subhorizontal, which generally could be related to an increase of the rock column that acted on the present erosion level in the Mühlzone. However, crustal thickening as late as $\sim 325 \mathrm{Ma}$ is not likely because Variscan collision, nappe thrusting and crustal thickening preceded the formation and emplacement of the South Bohemian Batholith (e.g., Büttner and Kruhl 1997; Büttner 1999, Gerdes et al. 2003). Therefore it is more likely that the magnitude of the subvertical stress vector, $\sigma_{3}$ during $\mathrm{D}_{2}$, remained roughly constant during the short period of transition from $\mathrm{D}_{2}$ to $\mathrm{D}_{3}$. The deposition of Variscan rocks as pebbles in late Viséan conglomerates of the MoravoSilesian Culm basin (Cháb and Suk 1976; Dvořák 1995; Hartley and Otava 2001) may even suggest erosion-related reduction of the rock column acting on the middle crust at this time.
We have seen that Viséan tectonic transport occurred in eastern and south-eastern direction along the SE margin of the Bohemian Massif - processes related to, and following, the post-collisional collapse and extension of the Variscan crust. The NW-SE crustal extension ( $\mathrm{D}_{3}$ in Büttner and Kruhl 1997) started at around $\sim 325 \mathrm{Ma}$ or a few million years earlier, coinciding, according to the most geochronologic data, with the emplacement of the earliest plutons of the batholith, the Rastenberg granodiorite $(323 \pm 2 \mathrm{Ma}$, Friedl et al. 1992, 1993) and the Weinsberg granite ( 331-323 Ma, Finger et al. 2003; Gerdes et al. 2003). Some older ages were reported for the emplacement of the Rastenberg granodiorite (338 \pm 2 Ma, Klötzli and Parrish 1996), which, however, appear to be in disagreement with the $P-T-d-t$ evolution of the country rock (Büttner and Kruhl 1997). 
At the mid-crustal level of the Mühlzone, the emplacement and crystallisation of the Weinsberg granite ( 331-323 Ma, Finger et al. 2003; Gerdes et al. 2003) coincided with the rotation of the stress field. The most likely explanation for the rotation of $\sigma_{3}$ from subvertical during $\mathrm{D}_{2}$ to subhorizontal during $\mathrm{D}_{3}$ appears to be late Viséan horizontal stress relaxation caused by NW-SE extension along the eastern orogen margin. Given that after the collision with Gondwana the southern margin of Laurasia was still under compression, keeping $\sigma_{1}$ constant in orientation, the stress vector that was affected by the NW-SE extension should have been $\sigma_{2}$. As soon as the magnitude of $\sigma_{2}$ dropped below the magnitude of $\sigma_{3}$, the stress field rotated and conjugate strike-slip zones replaced the subhorizontal magmatic shearing. The extension direction (NW-SE) was not parallel to $\sigma_{2}$ of $\mathrm{D}_{2}$. This might have caused minor stress field rotation that brought $\sigma_{1}$ into a more southerly position. Accordingly, $\mathrm{D}_{3}$ 's $\sigma_{3}$ plunges more easterly than $\mathrm{D}_{2}$ 's $\sigma_{2}$ (Fig. $4 \mathrm{~d}$ ).

The absolute magnitudes of individual stress vectors have not been determined. However, the lithostatic pressure during the in situ formation of the Schlieren granite of roughly $460 \mathrm{MPa}$ (Büttner 1999) suggests a vertical stress of that size during magma solidification. The very low shear strength of the Weinsberg and Schlieren granites during magmatic flow might not have allowed large differential stresses to build up. Small differential stress during the magmatic stage is also suggested by occasional $\mathrm{D}_{2}$ stress field variations as seen near St. Martin, which are more likely to occur in near-spherical stress fields. Hence, only little stress release by $\sim \mathrm{SE}-\mathrm{NW}$ extension was sufficient to facilitate the almost instant stress vector rotation after $\mathrm{D}_{2}$. Small differential stresses were probably also common during $\mathrm{D}_{3}$, because at normal strain rates $\left(\sim 10^{-14} \mathrm{~s}^{-1}\right)$ and amphibolite-facies temperatures, differential stresses $\leq 20 \mathrm{MPa}$ are sufficient to facilitate steady-state plastic flow in quartz-dominated rocks (e.g., Wilks and Carter 1990). However, the high strain rates suggested by microstructures present in the Rodl shear zone (Fig. 2d) require significantly higher differential stresses to form.

The possible kinematic link between subhorizontal and steep shearing in collisional orogens has received little attention in the existing literature. Tectonic patterns similar to those in the Mühlzone are known from the Neoproterozoic basement in SE Brazil (Ebert et al. 1996; Spanner and Kruhl 2002) and occur also in the Mesoproterozoic Namaqua Belt of South Africa (Rowland 2006; Büttner, unpublished data). Prerequisites for the transition from subhorizontal to steep strike-slip shearing during crustal shortening appear to be (i) low shear strength in highly ductile or partially molten middle or lower crust, allowing efficient shearing at low differential stress, or at least similar $\sigma_{2}$ and $\sigma_{3}$ values; (ii) an orogen geometry that permits lateral stretching during ongoing contraction, facilitating (iii) horizontal stress release reducing the intermediate horizontal stress vector, which then becomes the minimum stress. Because these prerequisites should frequently be realised in the middle crust of contracting magmatic arcs and collision orogens, late-orogenic stress field rotation approximately around $\sigma_{1}$ might be commonly associated with significant changes in tectonic style, such as the initiation of late orogenic escape tectonics.

Acknowledgements Field work and the costs of age dating were supported by the Deutsche Forschungsgemeinschaft within the Schwerpunktprogramm "Orogene Prozesse - ihre Quantifizierung und Simulation am Beispiel der Varisziden" (DFG grants Kr 69/16 and Bu 990/2-1). Gertrude Friedl from the ARGONAUT laboratory at the University of Salzburg is thanked for the Ar-Ar age dating of magmatic amphiboles. Jiří Žák and Gernold Zulauf have supplied valuable comments in their reviews. Vojtěch Janoušek is thanked for smooth editorial handling of the manuscript.

\section{References}

Brandmayr M, Dallmeyer RD, Handler R, Wallbrecher E (1995) Conjugate shear zones in the southern Bohemian Massif (Austria): implications for Variscan and Alpine tectonothermal activity. Tectonophysics 248: 97-116

Brandmayr M, Loizenbauer JV, Wallbrecher E (1997) Contrasting P-T conditions during conjugate shear zone development in the Southern Bohemian Massif, Austria. Mitt Österr Geol Ges 90: 11-29

BüTTNER SH (1997) Die spätvariszische Krustenentwicklung in der südlichen Böhmischen Masse: Metamorphose, Krustenkinematik und Plutonismus. PhD thesis, Frankfurter Geowiss Arb 16: pp 1-205

BütTNER SH (1999) The geometric evolution of structures in granite during continuous deformation from magmatic to solid-state conditions: an example from the central European Variscan Belt. Amer Miner 84: 1781-1792

BütTNER S, KRUHL JH (1997) The evolution of a late-Variscan high-T/low-P region: the southeastern margin of the Bohemian Massif. Geol Rundsch 86: 21-38

CARswell DA, O'Brien PJ (1993) Thermobarometry and geotectonic significance of high-pressure granulites: examples from the Moldanubian Zone of the Bohemian Massif in Lower Austria. J Petrol 34: 427-459

СнÁB J, Suk M (1976) The metamorphic development of the Bohemian Massif on the Czechoslovak territory. Sbor Geol Věd 31: 109-126 
DAHL PS (1996) The effects of composition on retentivity of argon and oxygen in hornblende and related amphiboles. Geochim Cosmochim Acta 60: 3687-3700

Dallmeyer RD, Franke W, Weber K (eds) (1995) Pre-Permian Geology of Central and Eastern Europe. SpringerVerlag, Berlin, pp 1-604

Davis GH, Reynolds SJ (1996) Structural geology of rocks and regions. John Wiley \& Sons, New York, pp 1-776

DvořÁk J (1995) Stratigraphy. In: Dallmeyer RD, Franke W, Weber K (eds) Pre-Permian Geology of Central and Eastern Europe. Springer-Verlag, Berlin, pp 477-489

Ebert HD, Chemale JR F, Babinski M, Artur AC (1996) Tectonic setting and $\mathrm{U} / \mathrm{Pb}$ dating of the plutonic Socorro Complex in the transpressive Rio Paraíba do Sul Shear Belt, SE Brazil. Tectonics 15: 688-699

FIALA J (1995) General characteristics of the Moldanubian Zone. In: Dallmeyer RD, Franke W, Weber K (eds) Pre-Permian Geology of Central and Eastern Europe. Springer-Verlag, Berlin, pp 417-418

Finger F, Doblmayr P, Friedl G, Gerdes A, Krenn E, von QuAdT A (2003) Petrology of the Weinsberg granite in the South Bohemian Batholith: New data from the mafic endmembers. J Czech Geol Soc 48: 46-47

FINGER F (1986) Die synorogenen Granitoide und Gneise des Moldanubikums im Gebiet der Donauschlingen bei Obermühl (Oberösterreich). Jb Geol B-A 128: 383-402

Finger F, Clemens JD (1995): Migmatization and ,secondary“" granitic magmas: effects of emplacement and crystallization of ,primary“" granitoids in Southern Bohemia, Austria. Contrib Mineral Petrol 120: 311-326

Finger F, Steyrer HP (1995) A tectonic model for the eastern Variscides: Indications from a chemical study of amphibolites in the south-eastern Bohemian Massif. Geol Carpath 46: 1-14

FrANKE W (1989) Tectonostratigraphic units in the Variscan belt of Central Europe. In: Dallmeyer RD (ed) Terranes in the Circum-Atlantic Paleozoic Orogens. Geol Soc Am Spec Pub 230: 67-90

Frasl G, Fuchs G, Kurzweil H, Thiele O, Vohryzaka K, ZIRKL E (1965) Übersichtskarte des Kristallins im westlichen Mühlviertel und im Sauwald, Oberösterreich. Maßstab 1: 100.000. Geol Bundesanst Wien

Friedl G, von QuAdt A, Finger F (1992) Erste Ergebnisse von $\mathrm{U} / \mathrm{Pb}$-Altersdatierungbearbeiten am Rastenberger Granodiorit im Niederösterreichischen Waldviertel. Mitt Österr Mineral Gesell 137: 131-143

Friedl G, von Quadt A, Ochsner A, Finger F (1993) Timing of the Variscan orogeny in the South Bohemian Massif (NE Austria) deduced from new U-Pb-zircon and monazite dating. Terra Abstr 5: 235-236

Friedl G, Cooke R, Finger F, McNaughton NJ, Fletcher I (2003) U-Pb SHRIMP dating and trace element investigations on multiple zoned zircons from a South Bohemian granulite. J Czech Geol Soc 48: 51
Fritz H, Neubauer F (1993) Kinematics of crustal stacking and dispersion in the south-eastern Bohemian Massif. Geol Rundsch 82: 556-565

Gerdes A, Friedl G, Parrish RR, Finger F (2003) Highresolution geochronology of Variscan granite emplacement - the South Bohemian Batholith. J Czech Geol Soc 48: 53-54

Gerdes A, Finger F, Parish RR (2006) Southwestward progression of a late-orogenic heat front in the Moldanubian Zone of the Bohemian Massif and formation of the Austro-Bavarian anatexite belt. Geoph Res Abstr 8: 10698

Handler R, Brandmayr M, Wallbrecher E (1991) The Rodl Shear Zone in the southern Bohemian Massif. Zbl Geol Paläont 1: 69-86

Handler R, Neubauer F, Velichkova SH, Ivanov Z (2004) ${ }^{40} \mathrm{Ar} /{ }^{39} \mathrm{Ar}$ age constraints on the timing of magmatism and post-magmatic cooling in the Panagyurishte region, Bulgaria. Schweiz Min Pet Mitt 84: 119-132

Hartley AG, Otava J (2001) Sediment provenance and dispersal in a deep marine foreland basin: the Lower Carboniferous Culm Basin, Czech Republic. J Geol Soc, London 158: 137-150

Kalt A, Corfu F, WiJbrans JR (2000) Time calibration of a P-T path from a Variscan high-temperature low-pressure metamorphic complex (Bayerischer Wald, Germany), and the detection of inherited monazite. Contrib Mineral Petrol 138: 143-163

KlÖtZli US, PARrish RR (1996) Zircon U/Pb and $\mathrm{Pb} / \mathrm{Pb}$ geochronology of the Rastenberg granodiorite, South Bohemian Massif, Austria. Mineral Petrol 58: 197-214

KRETz R (1983) Symbols for rock-forming minerals. Amer Miner 68: 277-279

KRUHL JH (1996) Prism- and basal-plane parallel subgrain boundaries in quartz: a microstructural geothermobarometer. J Metamorph Geol 14: 581-589

O'Brien PJ, CARswell DA(1993) Tectonometamorphic evolution of the Bohemian Massif: evidence from high-pressure metamorphic rocks. Int J Earth Sci 82: 531-555

Passchier CW, Trouw AJ (2005) Microtectonics. SpringerVerlag, Berlin, pp 1-366

PAterson SR, Vernon RH, ToBisch OT (1989) A review of criteria for the identification of magmatic and tectonic foliations in granitoids. J Struct Geol 11: 349-363

RaceK M, ŠTíPskÁ P, Pitra P, Schulmann K, Lexa O (2006) Metamorphic record of burial and exhumation of orogenic lower and middle crust: a new tectonothermal model for the Drosendorf Window (Bohemian Massif, Austria). Mineral Petrol 86: 221-251

Roberts MP, Finger F (1997) Do U-Pb zircon ages from granulites reflect peak metamorphic conditions? Geology 25 : 319-322

Rowland AE (2006) A structural investigation of the Namaqua Metamorphic Complex rocks exposed on Swart- 
modder and Oup Farms. Unpublished Honours Thesis, Rhodes University, pp 1-40

Scheuvens D, Zulauf G (2000) Exhumation, strain localization, and emplacement of granitoids along the western part of the Central Bohemian shear zone (Central European Variscides, Czech Republic). Int J Earth Sci 89: 617-630

Siebel W, Blaha U, Chen F, Rohrmüller J (2005) Geochronology and geochemistry of a dyke-host rock association and implications for the formation of the Bavarian Pfahl shear zone, Bohemian Massif. Int J Earth Sci 94: 8-23

SpanNer B, KRUHL JH (2002) Syntectonic granites in thrust and strike-slip regimes: the history of the Carmo and Cindacta plutons (southeastern Brazil). J South Am Earth Sci 15: 431-444

ŠTíPSKÁ P, SCHULMANn K, KÖNER A (2004) Verical extrusion and middle crustal spreading of omphacite granulite: a model of syn-convergent exhumation (Bohemian Massif, Czech Republic). J Metamorph Geol 22: 179-198

Teipel U, EichHorn R, Loth G, Rohrmüller J, Höll R, KenNEDY A (2004) U-Pb SHRIMP data and Nd isotopic data from the western Bohemian Massif (Bayerischer Wald, Germany): implications for Upper Vendian and Lower Ordovician magmatism. Int J Earth Sci 93: 782-801

Urban M, Synek J (1995) Structure In: Dallmeyer RD, Franke W, Weber K (eds) Pre-Permian Geology of Central and Eastern Europe. Springer-Verlag, Berlin, pp 429-443

VERNON RH (2000) Review of microstructural evidence of magmatic and solid-state flow. Electr Geosci 5: 2

Voll G (1976) Recrystallization of quartz, biotite, feldspars from Erstfeld to the Leventina Nappe, Swiss Alps, and its geological significance. Schweiz Mineral Petrogr Mitt 56: 641-647

Wilks KR, CARTER NL (1990) Rheology of some lower crustal rocks. Tectonophysics 182: 57-77

Zulauf G, Bues C, Dörr W, Vejnar Z (2002) $10 \mathrm{~km}$ minimum throw along the West Bohemian shear zone: evidence for dramatic crustal thickening and high topography in the Bohemian Massif(European Variscides). Int J Earth Sci 91: 850-864 